\title{
Isolasi dan karakterisasi bakteri yang berpotensi mengikat aflatoksin di rumen sapi
}

\section{Isolation and characterization of the aflatoxin binding bacteria in the rumen of cattle}

\author{
Dwi Sisriyenni $^{1}$, Suryahadi ${ }^{2}$, Komang G Wiryawan ${ }^{2}$, Dwierra Evvyernie ${ }^{2}$, Dadik Pantaya ${ }^{3 *}$ \\ ${ }^{1}$ Balai Pengkajian Teknologi Pertanian Riau. Jl. Kaharuddin Nasution KM. 10 No. 341 Pekanbaru. Riau. Indonesia. \\ 28284 \\ ${ }^{2}$ Departemen Ilmu Nutrisi dan Makanan Ternak. Fakultas Peternakan, Institut Pertanian Bogor. Jl. Agatis, Kampus \\ Darmaga. Bogor. 166680 \\ ${ }^{3}$ Program Studi Manajemen Bisnis Unggas. Jurusan Peternakan. Politeknik Negeri Jember. Jl. Mastrip Kotak Pos \\ 164. Jember. Jawa Timur. 68124 \\ *Email Koresponden: dadik_pantaya@polije.ac.id
}

\begin{tabular}{|c|c|}
\hline ARTICLE INFO & A B S T R A K \\
\hline $\begin{array}{l}\text { Received: } \\
\text { 18 February } 2021 \\
\text { Accepted: } \\
\text { 18 March } 2021 \\
\text { Published: } \\
\text { 31 March } 2021\end{array}$ & $\begin{array}{l}\text { Tujuan dari penelitian ini adalah untuk mengetahui pengaruh aflatoksin terhadap } \\
\text { fermentasi rumen secara in vitro dan untuk mendapatkan isolat bakteri rumen } \\
\text { yang mampu mengikat aflatoksin. Percobaan terdiri dari tiga tahap, tahap pertama } \\
\text { adalah penurunan aflatoksin didalam rumen yang dilakukan secara in vitro. Tahap } \\
\text { kedua adalah isolasi dan karakterisasi bakteri rumen yang bisa mengikat aflatoksin, } \\
\text { dan tahap ketiga adalah uji daya ikat aflatoksin oleh bakteri rumen. Penelitian } \\
\text { ini menggunakan rumen sapi yang didapatkan dari rumah potong hewan (RPH) } \\
\text { Bubulak Bogor. Rancangan penelitian menggunakan rancangan acak kelompok } \\
\text { (RAK) faktorial } 2 \text { x3 dan } 2 \text { ulangan. Faktor pertama adalah kandungan aflatoksin } \\
\text { (tanpa dan penambahan aflatoksin), faktor kedua adalah jenis pakan (ransum dan } \\
\text { glukosa), dan faktor ketiga adalah waktu inkubasi (0 dan } 4 \text { jam). Hasil penelitian } \\
\text { menunjukkan kandungan aflatoksin tidak mempengaruhi kondisi rumen (pH, } \\
\text { Volattile Fatty Acid (VFA), dan konsentrasi asam laktat rumen), dari hasil isolasi } \\
\text { didapatkan } 6 \text { isolat dan bakteri rumen yang dapat mengikat aflatoksin hingga } 50 \% \text {. }\end{array}$ \\
\hline & A B S T R A C T \\
\hline $\begin{array}{l}\text { Key words: } \\
\text { Aflatoxin } \\
\text { Rumen bacteria } \\
\text { Bacterial isolation }\end{array}$ & $\begin{array}{l}\text { The purpose of this study was to examine the influence of aflatoxins on rumen } \\
\text { fermentation in vitro and obtained rumen bacterial isolates capable of binding } \\
\text { aflatoxin. This trial consisted of three stages. The first trial was a reduction of } \\
\text { aflatoxin in the rumen in vitro. The second experiment was the isolation and } \\
\text { characterization of rumen bacteria that could bind aflatoxin. The third stage was to } \\
\text { test the holding capacity of aflatoxin by rumen bacteria. This study used cow rumens. } \\
\text { The Research design used a randomized complete block design (RCBD) factorial } 2 \times 3 \\
\text { and } 2 \text { replications. The first factor was the presence of aflatoxin (with and without } \\
\text { the addition of aflatoxin), the second factor was the type of feed (diet and glucose), } \\
\text { and the third factor was the time of incubation ( } 0 \text { and } 4 \text { hours). The results showed } \\
\text { the presence of aflatoxin did not affect rumen conditions (pH, volatile fatty acid } \\
\text { (VFA), and rumen lactic acid concentration), and the results obtained } 6 \text { isolates and } \\
\text { isolation of rumen bacteria to bind aflatoxin up to } 50 \% \text {. }\end{array}$ \\
\hline
\end{tabular}

\section{PENDAHULUAN}

Aflatoksin adalah produk senyawa metabolit sekunder yang dihasilkan oleh spesies Aspergillus yaitu Aspergillus flavus dan Aspergillus parasiticus (Yao, Gao, Ding, Zhang, and $\mathrm{Li}, 2021$ ). Aflatoksin dapat tumbuh pada bahan pakan pada masa pertumbuhan hingga 
panen, pada proses penyimpanan dan juga pada saat transportasi. Secara kimiawi, aflatoksin adalah kelompok turunan difuranocoumarin yang menunjukkan fluoresensi di bawah sinar ultraviolet. Berdasarkan warna fluoresensi aflatoksin dikelompokkan menjadi aflatoksin B1 dan B2 (AFB1, AFB2) berwarna biru, serta G1 dan G2 (AFG1, AFG2) berwarna hijau, angka 1 dan 2 menunjukkan perbedaan antar senyawa utama dan tambahan (Firmin, Morgavi, Yiannikouris, \& Boudra, 2011). Aflatoksin B2 merupakan derivat dari B1 dan G2 merupakan derivat dari G1. Aflatoksin B1 (AFB1) diketahui yang paling berbahaya di antara keempat jenis aflatoksin lainnya, sehingga pengembangan penelitian banyak difokuskan pada aflatoksin B1.

Aflatoksin pada hewan dapat menyebabkan kerusakan hati, gangguan saluran pencernaan, produktivitas, efisiensi pemanfaatan pakan, penurunan kinerja reproduksi, mengurangi produksi susu atau telur, kematian embrio, teratogenisitas (cacat lahir), tumor dan menekan fungsi sistem kekebalan tubuh (Park, Park, Song, \& Lim, 2019). Gejala penyakit yang ditimbulkan tergantung pada hewan, dosis, lama paparan, spesies dan diet atau status gizi.

Detoksifikasi bahan pakan yang terkontaminasi aflatoksin baik secara fisik dan kimia dalam pelaksanaannya kurang praktis, tidak efisien dan membutuhkan biaya yang besar. Selain itu, juga memiliki keterbatasan sehubungan dengan pertimbangan keamanan karena dapat membuat produk tercemar bahan kimia yang akan dapat merusak nilai nutrisi produk. Liu, Wang, Deng, Gu, \& Wang (2018) melaporkan bahwa detoksifikasi secara kimia menggunakan arang aktif dan sodium terhidrasi aluminium silikat dengan persentase rendah tidak efektif untuk mengatasi jamur pada bahan pakan, karena absorben dapat mengikat nutrisi penting sehingga dapat menyebabkan efek negatif.

Bakteri rumen khususnya bakteri asam laktat (BAL) bersama yeast sebagai adsorben biologis dapat mencegah perpindahan aflatoksin kedalam saluran usushewan. Mikrobarumen dapat mengubah mikotoksin menjadi metabolik non toksik pada saluran pencernaan hewan sebelum diserap dalam saluran pencernaan. Aflatoksin B1 oleh mikroba dirubah menjadi B2, B2a, dan M1. Carulla, Kreuzer, Machmüller, and Hess (2005) melaporkan biotransformasi, pembelahan dan detoksifikasi molekul mikotoksin oleh mikroba atau pun enzim adalah metode yang efektif dan lebih aman dalam mengontrol mikotoksin. Gallo et al. (2020) melaporkan terjadi degradasi sebanyak $42 \%$ aflatoksin saat diinkubasi secara in vitro menggunakan cairan rumen. Pendapat berbeda disampaikan oleh Pantaya et al. (2016) yang melaporkan bahwa mikroorganisme rumen mampu mendegradasi seluruh mikotoksin yang diuji kecuali AFB1.

Asam laktat merupakan hasil fermentasi karbohidrat dari hijauan di dalam rumen. Semakin tinggi asam laktat di dalam rumen akan mengakibatkan $\mathrm{pH}$ turun sehingga mikrobamikroba rumen yang tidak tahan kondisi asam akan mati dan dapat mengganggu proses fermentasi di dalam rumen. Bakteri asam laktat dapat digunakan untuk menghambat produksi aflatoksin (Jiang et al., 2020). Pengikatan aflatoksin oleh BAL berlangsung secara cepat tidak lebih dari 60 menit tergantung pada konsentrasi aflatoksin (Gonçalves et al., 2020).

Penelitian tentang pengaruh aflatoksin terhadap kondisi fermentasi rumen dan kemampuan bakteri rumen dalam mengikat aflatoksin belum pernah dilaporkan di Indonesia. Penelitian ini bertujuan mengetahui pengaruh aflatoksin terhadap fermentasi rumen secara in vitro dan mendapatkan isolat bakteri rumen yang mampu mengikat aflatoksin.

\section{MATERI DAN METODE}

\section{Penurunan Aflatoksin di dalam Rumen secara In vitro}

Penelitian ini bertujuan untuk mengetahui penurunan aflatoksin oleh bakteri rumen secara in vitro pada berbagai kondisi jenis pakan, lama inkubasi dan faktor konsentrasi aflatoksin. Sumber bakteri yang digunakan berasal dari rumah potong hewan (RPH) Bubulak Bogor. Cairan rumen sebanyak $500 \mathrm{ml}$ disaring menggunakan saringan polyester ukuran 250$\mu \mathrm{m}$. Teknik isolasi dan inkubasi dengan metode Goering, H.K. and Van Soest, (1970) menggunakan $25 \mathrm{~mL}$ larutan buffer sitrat phosphate dan 15 $m$ cairan rumen untuk analisis pengikatan aflatoksin. Adapun analisis VFA menggunakan $0,8 \mathrm{ml}$ cairan rumen yang dicampur dengan 0,5 $\mathrm{mL}$ dari $0,4 \mathrm{mg} / \mathrm{mL}$ asam crotonic dan $20 \mathrm{mg} /$ $\mathrm{ml}$ asam metaphosphoric dalam 0,5 $\mathrm{N} \mathrm{HCl}$ dan disimpan dalam suhu $-20^{\circ} \mathrm{C}$ sampai dilakukan dianalisis (Pantaya et al., 2016). Larutan asam 
laktat sebanyak $2 \mathrm{~mL}$ diletakkan dalam tube, disimpan sampai dilakukan analisis Pakan yang digunakan dalam percobaan ini menggunakan formulasi rumput gajah (Pennisetum purpureum) $8 \%$, konsentrat $14 \%$, dan mineral $1 \%$. Konsentrat yang digunakan mempunyai kandungan Neutral Detergent Acid (NDF) 54,2\% BK, acid detergent fiber (ADF) 31,8\%, dan protein kasar (PK) 8,4\%.

Rancangan percobaan yang dilakukan adalah rancangan acak kelompok faktorial (RAK faktorial) $2 \times 3$ diulang 2 kali. Faktor A adalah aflatoksin yaitu $\mathrm{A} 1$ = tanpa aflatoksin dan $\mathrm{A} 2=$ penambahan aflatoksin 20 ppb. Faktor B adalah pakan, $\mathrm{B} 1=$ ransum $(15 \%$ hijauan dan $85 \%$ konsentrat) dan B2 = glukosa. Faktor $\mathrm{C}$ adalah waktu inkubasi yaitu $\mathrm{C} 1$ = inkubasi 0 jam dan $\mathrm{C} 2$ = inkubasi selama 4 jam. Peubah yang diukur sebelum dan setelah fermentasi rumen adalah $\mathrm{pH}$, konsentrasi volatile fatty acid (VFA) yang diukur dengan teknik destilasi uap (Mansfield et al., 1995), kadar asam laktat dianalisis kandungan aflatoksinnya menggunakan Thin Layer Chromatography (TLC) (Pantaya et al., 2016).

\section{Isolasi dan Karakterisasi Bakteri Rumen Pendegradasi Aflatoksin}

Sebagai tindak lanjut percobaan tahap kedua dilakukan isolasi dan karakterisasi bakteri rumen yang mampu menurunkan kadar aflatoksin. Prosedur isolasi bakteri, pembuatan media tumbuh dan media pengencer dilakukan berdasarkan prosedur persiapan media (Ogimoto, 1981). Sumber bakteri yang digunakan adalah dari kultur bakteri yang menghasilkan persentase penurunan aflatoksin tertinggi.

Setelah didapatkan kultur murni. maka dilanjutkan dengan karakterisasi yaitu 1) Pewarnaan gram (Cappucino, 2011), 2) Pewarnaan endospore (Lay, 1994), 3) uji katalase (Lay, 1994) dan 4) uji motilitas (Barrow, G. I. and Feltham,1993). Data yang diperoleh dikemukakan secara deskriptif.

\section{Pengikatan Aflatoksin oleh Bakteri Rumen}

Setelah didapatkan kultur murni bakteri rumen yang mampu menurunkan kadar aflatoksin didalam rumen, selanjutnya dilakukan pengujian lebih lanjut tentang kemampuannya dalam mengikat aflatoksin pada dinding sel bakteri. Tahapan ini mengkaji kerja bakteri rumen dalam mengikat aflatoksin. Prosedur pengujian daya ikat mengacu pada (El-Nezami, Mykkänen, Kankaanpää, Salminen, \& Ahokas, 2000). Bahan yang digunakan dalam penelitian ini adalah dua kultur murni bakteri rumen hasil dari isolasi bakteri pada percobaan dua, larutan standar aflatoksin (Sigma Aldrich).

Prosedur pelaksanaan pada tahap ini yaitu larutan kultur bakteri disentrifugasi pada putaran 3500 x g selama 10 menit. Supernatan dibuang dan endapan pelet dikultur in vitro dalam suatu media broth pada kondisi anaerob suhu $37^{\circ} \mathrm{C}$ selama 60 menit. selanjutnya media tersebut ditambahkan aflatoksin dengan konsentrasi akhir 100 ppb. Setelah diinkubasikan suspensi bakteri dan AFB1, dilakukan sentrifugasi selama $3500 \mathrm{rpm}$ selama 10 menit. Endapan dibuang dan supernatan dikoleksi untuk ditetapkan kadar AFB1 dengan Liquid Chromatography Mass Spectrophtometer (LCMS-MS). Sebagai kontrol dilakukan prosedur yang sama tetapi medium tidak diinokulasikan dengan bakteri. Peubah yang diukur adalah kadar aflatoksin setelah inkubasi selama 60 menit.

Daya ikat aflatoksin oleh bakteri rumen didefinisikan sebagai berikut: [(Kadar aflatoksin kontrol - Kadar aflatoksin sampel)/Kadar aflatoksin kontrol] x 100\% (Kankaanpää, Tuomola, El-Nezami, Ahokas, \& Salminen, 2000).

Peubah yang diukur adalah pengikatan aflatoksin oleh bakteri menggunakan Liquid Chromatography Mass Spectrophtometer (LCMSMS) mengacu pada modifikasi Silva, Pena, Lino, Fernández, and Mañes (2010). Data yang diperoleh dikemukakan secara deskriptif.

\section{HASIL DAN PEMBAHASAN}

\section{Penurunan Aflatoksin dalam Rumen secara In vitro}

Untuk menentukan kemampuan bakteri rumen dalam mendegradasi aflatoksin, di dalam sistem fermentasi rumen harus dilakukan dengan penambahan aflatoksin dalam rumen. Degradasi dapat disebabkan oleh bakteri itu sendiri, mikroba rumen lainnya atau bisa juga disebabkan oleh perubahan kimia aflatoksin di dalam rumen. Kondisi rumen harus ideal untuk pertumbuhan bakteri rumen, oleh karena itu bakteri rumen yang mampu mendegradasi aflatoksin dari rumen yang memiliki kondisi fisikokimia yang ideal. Pengukuran terhadap nilai $\mathrm{pH}, \mathrm{VFA}$, asam laktat dan kadar aflatoksin untuk melihat ideal atau 
Tabel 1. Nilai pH rumen

\begin{tabular}{|c|c|c|c|c|c|}
\hline \multirow{2}{*}{ Faktor Perlakuan } & & \multirow[t]{2}{*}{ Aflatoksin } & \multicolumn{2}{|c|}{ Waktu Inkubasi (jam) } & \multirow[t]{2}{*}{ Rataan } \\
\hline & & & 0 & 4 & \\
\hline \multirow{6}{*}{ Pakan } & Ransum & - & $6,82 \pm 0,056$ & $6,30 \pm 0,056$ & $6,56 \pm 0,303$ \\
\hline & & + & $6,96 \pm 0,113$ & $6,40 \pm 0,092$ & $6,68 \pm 0,336$ \\
\hline & & rataan & $6,89 \pm 0,098$ & $6,35 \pm 0,070$ & $6,62 \pm 0,381$ \\
\hline & Glukosa & - & $6,73 \pm 0,077$ & $6,28 \pm 0,091$ & $6,51 \pm 0,268$ \\
\hline & & + & $6,89 \pm 0,084$ & $6,15 \pm 0,148$ & $6,52 \pm 0,435$ \\
\hline & & rataan & $6,81 \pm 0,116$ & $6,22 \pm 0,122$ & $6,51 \pm 0,417$ \\
\hline \multirow[t]{2}{*}{ Aflatoksin } & Rataan & - & $6,78 \pm 0,078$ & $6,29 \pm 0,063$ & $6,53 \pm 0,268$ \\
\hline & & + & $6,93 \pm 0,091$ & $6,28 \pm 0,171$ & $6,60 \pm 0,369$ \\
\hline Waktu fermentasi & & rataan & $6,85^{a} \pm 0,113$ & $6,28^{\mathrm{b}} \pm 0,119$ & $6,56 \pm 0,403$ \\
\hline
\end{tabular}

${ }^{\mathrm{a}, \mathrm{b}}$ Superskrip yang berbeda pada baris yang sama memperlihatkan perbedaan yang nyata $(\mathrm{P}<0,05)$

tidaknya kondisi rumen dengan penambahan aflatoksin. Berikut ini ditampilkan data nilai $\mathrm{pH}$, konsentrasi VFA, kadar asam laktat dan kadar aflatoksin perlakuan.

\section{Nilai $\mathbf{p H}$ rumen}

Nilai pH rumen ditampilkan pada Tabel 1. Derajat keasaman $(\mathrm{pH})$ cairan rumen merupakan salah satu indikator yang menunjukkan berlangsungnya kegiatan bioproses di dalam rumen. Nilai pH rumen berkisar 6,15 - 6,96. Konsentrasi $\mathrm{pH}$ dipengaruhi oleh faktor waktu, terjadi penurunan $\mathrm{pH}$ sebanyak $8,32 \%$ setelah inkubasi selama 4 jam $(\mathrm{P}>0,05)$. Penurunan $\mathrm{pH}$ setelah 4 jam inkubasi terjadi karena asam yang dihasilkan. Nilai ini menunjukkan bahwa pada waktu itu sudah dihasilkan produk fermentasi berupa VFA yang optimal. Hal ini terlihat pada konsentrasi VFA cairan rumen yang cukup tinggi dengan kisaran 122,27 - 151,58 mM. Konsentrasi VFA yang cukup tinggi ini akan mempengaruhi $\mathrm{pH}$ rumen karena produk fermentasi dalam bentuk VFA terakumulasi di dalam tabung fermentor.

Walaupun terjadi penurunan $\mathrm{pH}$, namun $\mathrm{pH}$ rumen masih berada pada kisaran normal. Kisaran pH rumen yang normal adalah 6 - 7 (Usman, 2013). Nilai ini menunjukkan bahwa fermentasi dalam rumen berlangsung secara optimal. Nilai $\mathrm{pH}$ rumen berkisar antara $6-7$ dan kondisi yang paling optimal untuk aktivitas bakteri rumen adalah 6,9.

Pemberian pakan dengan rasio konsentrat yang lebih tinggi dibandingkan hijauan, dan pakan glukosa yang fermentabel di rumen juga tidak menggertak terjadinya kondisi asidosis, karena
pH rumen masih berada pada kisaran normal. Begitu juga dengan penambahan aflatoksin tidak mempengaruhi kondisi $\mathrm{pH}$ rumen, dengan demikian penambahan aflatoksin tidak mengurangi $\mathrm{pH}$ rumen, proses fermentasi secara keseluruhan tidak berubah. Nilai pH rumen masih berada dalam kondisi normal.

\section{Konsentrasi VFA rumen}

Konsentrasi VFA rumen ditampilkan pada Tabel 2. VFA merupakan produk fermentasi karbohidrat dalam rumen, semakin tinggi jumlah VFA, menunjukkan ketersediaan energi semakin besar. Faktor pakan, aflatoksin dan waktu fermentasi tidak berpengaruh $(\mathrm{P}>0,05)$ terhadap konsentrasi VFA rumen setelah proses fermentasi selama 4 jam. Hal ini mengindikasikan bahwa aflatoksin, jenis pakan dan waktu inkubasi tidak mengganggu proses fermentasi bahan pakan di dalam rumen.

Konsentrasi VFA merupakan salah satu produk fermentasi karbohidrat oleh mikroba rumen disamping produk lainnya yaitu $\mathrm{CO}_{2}$ dan $\mathrm{CH}_{4}$. Volatile Fatty Acid merupakan sumber energi utama bagi ternak ruminansia, konsentrasi VFA hasil penelitian ini berkisar 110,24 - 165,37 mM, konsentrasi ini hampir sama dengan konsentrasi VFA yang dilaporkan oleh Gallo et al. (2020) yaitu sekitar 138,57 mM pada sapi laktasi dan 124,56 mM pada sapi kering kandang. Konsentrasi VFA masih berada pada kisaran normal, berarti penambahan aflatoksin tidak mempengaruhi proses fermentasi di dalam rumen hal ini ditunjukkan dengan nilai $\mathrm{pH}$ yang normal. Selanjutnya Rahayu, Subrata, and Achmadi (2018) 
Tabel 2. Konsentrasi VFA (mM) rumen

\begin{tabular}{|c|c|c|c|c|c|}
\hline \multirow{2}{*}{\multicolumn{2}{|c|}{ Faktor Perlakuan }} & \multirow[t]{2}{*}{ Aflatoksin } & \multicolumn{2}{|c|}{ Waktu Inkubasi (jam) } & \multirow[t]{2}{*}{ Rataan } \\
\hline & & & 0 & 4 & \\
\hline \multirow{6}{*}{ Pakan } & Ransum & - & $140,31 \pm 42,518$ & $135,29 \pm 21,267$ & $137,80 \pm 27,598$ \\
\hline & & + & $140,31 \pm 42,518$ & $120,27 \pm 42,518$ & $130,29 \pm 36,593$ \\
\hline & & Rataan & $140,31 \pm 34,716$ & $127,78 \pm 28,785$ & $134,05 \pm 30,273$ \\
\hline & Gluoksa & - & $160,35 \pm 14,170$ & $125,28 \pm 21,267$ & $142,82 \pm 20,863$ \\
\hline & & + & $165,37 \pm 21,267$ & $110,24 \pm 14,170$ & $137,81 \pm 35,079$ \\
\hline & & Rataan & $162,86 \pm 15,033$ & $117,76 \pm 17,116$ & $140,31 \pm 25,127$ \\
\hline \multirow[t]{2}{*}{ Aflatoksin } & Rataan & - & $150,33 \pm 28,345$ & $130,29 \pm 18,299$ & $140,31 \pm 24,548$ \\
\hline & & + & $152,84 \pm 31,026$ & $115,26 \pm 17,116$ & $134,05 \pm 33,427$ \\
\hline \multicolumn{2}{|c|}{ Waktu fermentasi } & Rataan & $151,59 \pm 27,544$ & $122,77 \pm 22,569$ & $137,18 \pm 28,515$ \\
\hline
\end{tabular}

menyatakan menunjang pertumbuhan mikroba yang optimum, konsentrasi VFA cairan rumen berkisar antara 80-160 mM. Adapun Mc Donald, A., JFD., and CA. (2002) menyatakan konsentrasi VFA dalam rumen bervariasi antara 0,2-1,5 g per $100 \mathrm{~mL}$ atau 10-70 $\mathrm{mmol} \mathrm{L}^{-1}$.

\section{Konsentrasi asam laktat rumen}

Kadar asam laktat ditampilkan pada Tabel 3. Faktor waktu dan faktor jenis pakan tidak berpengaruh terhadap kadar asam laktat di dalam rumen, namun faktor aflatoksin berpengaruh nyata $(\mathrm{P}<0,05)$ meningkatkan kadar asam laktat rumen. Kadar asam laktat berada pada kisaran 0,34 - 0,72 $\mathrm{mg} / \mathrm{ml}$. Terjadi peningkatan kadar asam laktat rumen $67,42 \%$ dengan penambahan aflatoksin. Asam laktat dapat menurunkan $\mathrm{pH}$ rumen, mengakibatkan kerusakan pada dinding sel bakteri yang terdiri dari polisakarida dan peptidoglikan.
Penambahan aflatoksin yang merupakan senyawa pepton dapat diserap oleh bakteri rumen untuk memperbaiki struktur dinding sel bakteri sehingga bakteri pembentuk asam laktat bertahan hidup dan menghasilkan asam laktat yang dapat menekan pertumbuhan bakteri lain. Asam laktat dijumpai didalam rumen ruminansia karena didalam rumen terdapat bakteri bakteri pembentuk laktat (Lettat et al., 2010). Menurut Wulandari, Agus, Cahyanto, \& Utomo (2014) asam laktat dapat menghasilkan $\mathrm{pH}$ yang rendah pada substrat sehingga dapat menimbulkan suasana asam.

\section{Kadar aflatoksin rumen}

Rataan kadar aflatoksin dalam rumen diperlihatkan pada Tabel 4. Penambahan aflatoksin dan jenis pakan tidak berpengaruh terhadap kadar aflatoksin dalam rumen. Penambahan waktu inkubasi dari 0 menjadi 4

Tabel 3. Konsentrasi asam laktat $(\mathrm{mg} / \mathrm{ml})$ rumen

\begin{tabular}{|c|c|c|c|c|c|}
\hline \multirow{2}{*}{ Faktor Perlakuan } & & \multirow[t]{2}{*}{ Aflatoksin } & \multicolumn{2}{|c|}{ Waktu Inkubasi (jam) } & \multirow[t]{2}{*}{ Rataan } \\
\hline & & & 0 & 4 & \\
\hline \multirow{6}{*}{ Pakan } & Ransum & - & $0,34 \pm 0,310$ & $0,72 \pm 0,016$ & $0,53 \pm 0,282$ \\
\hline & & + & $0,68 \pm 0,095$ & $0,70 \pm 0,403$ & $0,69 \pm 0,275$ \\
\hline & & Rataan & $0,51 \pm 0,253$ & $0,71 \pm 0,026$ & $0,61 \pm 0,258$ \\
\hline & Gluoksa & - & $0,34 \pm 0,079$ & $0,37 \pm 0,365$ & $0,36 \pm 0,216$ \\
\hline & & + & $0,67 \pm 0,079$ & $0,56 \pm 0,024$ & $0,62 \pm 0,08$ \\
\hline & & Rataan & $0,51 \pm 0,205$ & $0,47 \pm 0,237$ & $0,49 \pm 0,206$ \\
\hline \multirow[t]{2}{*}{ Aflatoksin } & Rataan & - & $0,34 \pm 0,185$ & $0,55 \pm 0,291$ & $0,44^{\mathrm{b}} \pm 0,223$ \\
\hline & & + & $0,68 \pm 0,072$ & $0,63 \pm 0,088$ & $0,65^{\mathrm{a}} \pm 0,796$ \\
\hline Waktu fermentasi & & Rataan & $0,51 \pm 0,223$ & $0,59 \pm 0,204$ & $0,55 \pm 0,210$ \\
\hline
\end{tabular}

${ }^{\mathrm{a}, \mathrm{b}}$ Superskrip yang berbeda pada kolom yang sama memperlihatkan perbedaan yang nyata $(\mathrm{P}<0,05)$. 
Tabel 4. Kadar aflatoksin total G1 dan G2 (ppb) rumen

\begin{tabular}{|c|c|c|c|c|c|}
\hline \multirow{2}{*}{ Faktor Perlakuan } & & \multirow[t]{2}{*}{ Aflatoksin } & \multicolumn{2}{|c|}{ Waktu Inkubasi (jam) } & \multirow[t]{2}{*}{ Rataan } \\
\hline & & & 0 & 4 & \\
\hline \multirow{6}{*}{ Pakan } & Ransum & - & $8,08 \pm 4,023$ & $4,67 \pm 2,771$ & $6,38 \pm 2,822$ \\
\hline & & + & $7,89 \pm 5,741$ & $4,08 \pm 1,202$ & $5,99 \pm 3,537$ \\
\hline & & rataan & $7,99 \pm 4,131$ & $4,38 \pm 1,746$ & $6,18 \pm 2,982$ \\
\hline & Glukosa & - & $9,51 \pm 2,184$ & $3,84 \pm 0,233$ & $6,68 \pm 1,139$ \\
\hline & & + & $7,74 \pm 1,018$ & $3,90 \pm 0,021$ & $5,82 \pm 0,588$ \\
\hline & & rataan & $8,63 \pm 1,317$ & $3,87 \pm 0,170$ & $6,25 \pm 0,881$ \\
\hline \multirow[t]{2}{*}{ Aflatoksin } & rataan & & $8,80 \pm 3,228$ & $4,26 \pm 2,725$ & $6,53 \pm 2,773$ \\
\hline & & & $7,82 \pm 4,695$ & $3,99 \pm 2,325$ & $5,90 \pm 3,461$ \\
\hline Waktu fermentasi & & rataan & $8,31^{\mathrm{a}} \pm 3,734$ & $4,12^{\mathrm{b}} \pm 2,347$ & $6,21 \pm 3,030$ \\
\hline
\end{tabular}

a, b Superskrip yang berbeda pada baris yang sama memperlihatkan perbedaan yang nyata $(\mathrm{P}<0,05)$

jam dapat menurunkan kadar aflatoksin cairan rumen $(\mathrm{P}<0,05)$, dimana terjadi penurunan kadar aflatoksin sebesar $50,36 \%$ setelah fermentasi dilakukan selama 4 jam.

Penurunan aflatoksin sejalan dengan penurunan $\mathrm{pH}$, adanya penurunan $\mathrm{pH}$ dapat mengakibatkan AFB1 berubah menjadi turunan aflatoksin seperti AFB2, AFB2a dan AFM1 oleh mikroba rumen, sehingga AFB1 tidak terdeteksi. Sutatdjid (1989) melaporkan pada pH rendah, AFB1 dirubah menjadi AFB2a, sedangkan Kiessling, Pettersson, Sandholm, \& Olsen (1984) menyatakan cairan rumen sapi atau domba dapat mengkonversi AFB1 menjadi AFM1. Aflatoksin yang terdeteksi adalah aflatoksin G1 dan G2 yang berasal dari pakan yang terbawa oleh cairan rumen. El-Nezami et al. (2000) melaporkan bahwa aflatoksin B2, G1 dan G2 kurang sensitif terhadap proses pengikatan, sehingga aflatoksin jenis ini dapat terdeteksi.

Penurunan aflatoksin terjadi setelah diinkubasi selama 4 jam. Penurunan ini diduga lebih disebabkan konversi AFB1 menjadi senyawa turunanya misalnya AFM1. Penurunan $\mathrm{pH}$ rumen diduga disebabkan oleh peningkatan asam laktat. Apabila pH rumen turun maka bakteri yang tahan asam (BAL) akan dapat hidup dengan baik. Kankaanpää, Tuomola, El-Nezami, Ahokas, and Salminen (2000) melaporkan penurunan kadar aflatoksin dalam cairan rumen juga sejalan dengan penurunan nilai $\mathrm{pH}$ karena suasana asam dapat merusak dinding sel bakteri sehingga mengakibatkan AFB1 dengan mudah diikat oleh konstituen membran sitoplasma. Mekanisme pengikatan AFB1 oleh bakteri dilakukan oleh polisakarida dinding sel dan peptidoglikan. Perubahan $\mathrm{pH}$ dapat menyebabkan peningkatan ukuran pori-pori, penurunan ketebalan dinding sel sehingga bakteri dapat mengikat aflatoksin. Pantaya et al. (2016) menyatakan bahwa kecepatan bakteri dalam mengikat toksin dipengaruhi oleh nilai $\mathrm{pH}$.

\section{Isolasi dan Identifikasi Bakteri Rumen}

Identifikasi dan karakteristik bakteri rumen ditampilkan pada Tabel 5. Hasil isolasi didapatkan 6 jenis bakteri. Pengujian dengan pewarnaan gram didapatkan isolat no 1 menunjukkan gram negatif dan lainnya gram positif. Uji katalase didapatkan 2 isolat (3 dan 6) memiliki katalase positif. Uji endospora semua isolat tidak menghasilkan endospora dan uji motilitas semua isolat bersifat motil ditandai dengan pergerakan flagella.

\section{Uji Pengikatan Aflatoksin oleh Isolat Bakteri Rumen}

Hasil analisis pengikatan AFB1 oleh bakteri rumen menggunakan LCMS-MS disajikan pada Tabel 6. Pengikatan AFB1 oleh bakteri rumen setelah masa inkubasi selama 60 menit masing-masing 53,59\% dan 51,68\%. Kedua isolat memiliki kemampuan yang hampir sama dalam mengikat AFB1 hanya selisih 1,91\%. Perbedaan populasi bakteri yang digunakan tidak berpengaruh terhadap daya ikat bakteri. Persentase pengikatan aflatoksin dipengaruhi oleh pH, suhu inkubasi dan konsentrasi AFB1. Pada percobaan ini konsentrasi aflatoksin di dalam media $100 \mathrm{ppb}$ dan suhu inkubasi $37^{\circ} \mathrm{C}$, sehingga pengikatan terhadap AFB1 nilainya 
Tabel 5. Karakteristik bakteri rumen yang tumbuh pada media aflatoksin

\begin{tabular}{llccccc}
\hline No & \multicolumn{1}{c}{ Bentuk } & $\begin{array}{c}\text { Pewarnaan } \\
\text { gram }\end{array}$ & Uji Katalase & Endospora & Motilitas & $\begin{array}{c}\text { Uji konfirmasi } \\
\text { pengikatan aflatoksin }\end{array}$ \\
\hline 1 & Coccus in cluster & - & - & - & + & belum diuji \\
2 & Coccus & + & - & - & + & + \\
3 & Curved Rod & - & - & - & + & belum diuji \\
4 & Cocci in chains & + & - & - & + & + \\
5 & Rod with square end & + & - & - & + & belum diuji \\
6 & Diplococcus & + & + & - & + & belum diuji \\
\hline
\end{tabular}

Tabel 6. Hasil pengikatan AFB1 oleh isolat bakteri rumen

\begin{tabular}{ccc}
\hline No & $\begin{array}{c}\text { Isolat Populasi } \\
(\mathrm{CFU} / \mathrm{ml})\end{array}$ & $\begin{array}{c}\text { Pengikatan AFB1 } \\
(\% / \mathrm{jam})\end{array}$ \\
\hline \multirow{2}{*}{1} & Isolat no 2 & 53,59 \\
& $7,1 \times 108$ & 51,68 \\
2 & Isolat no 4 & \\
\hline
\end{tabular}

hampir sama. El-Nezami et al. (2000) menyatakan bahwa jumlah aflatoksin B1 yang terikat oleh bakteri meningkat seiring dengan meningkatnya konsentrasi aflatoksin B1. Sejalan dengan hasil laporan Lee et al. (2003) yang menyatakan bahwa rata-rata kecepatan pengikatan AFB1 oleh bakteri tergantung pada konsentrasi aflatoksin. Semakin tinggi aflatoksin yang tersedia di sekitar sel bakteri, maka semakin tinggi pula kesempatan aflatoksin dan sel bakteri berinteraksi sehingga proses pengikatan berlangsung dengan cepat.

Haskard, El-Nezami, Kankaanpää, Salminen, and Ahokas (2001) melaporkan dalam keadaan hidup bakteri memiliki pertahanan diri sehingga tidak semua aflatoksin B1 akan terikat pada komponen sel dari bakteri, namun demikian, ketika racun pada media tinggi maka bakteri akan mengikat lebih banyak.

\section{KESIMPULAN}

Penambahan aflatoksin sampai $20 \mathrm{ppb}$ di dalam rumen tidak mempengaruhi karakteristik kimiawi rumen, seperti $\mathrm{pH}, \mathrm{VFA}$, asam laktat dan aktivitas mikroba rumen. Bakteri rumen mampu mengurangi kadar aflatoksin dalam rumen melalui pengikatan ke dalam dinding sel bakteri rumen dengan waktu inkubasi selama 4 jam. Beberapa bakteri rumen yang memiliki kemampuan tersebut dapat diisolasi dan memiliki kemampuan untuk menurunkan kadar aflatoksin hingga $50 \%$.

\section{DAFTAR PUSTAKA}

Barrow, G. I.; Feltham, R. K. A. (1993). Cowan and Steel's Manual for The Identification of Medical Bacteria. Cambridge: Cambridge University Press.

Cappucino, J. G. . S. N. (2011). Microbiology: $a$ Laboratory Manual (9th ed.). Adviso Wesley Pub. Comp. Inc. USA.

Carulla, J. E., Kreuzer, M., Machmüller, A., \& Hess, H. D. (2005). Supplementation of Acacia mearnsii tannins decreases methanogenesis and urinary nitrogen in forage-fed sheep. Australian Journal of Agricultural Research, 56(9), 961-970. doi:https://doi.org/10.1071/AR05022

El-Nezami, H., Mykkänen, H., Kankaanpää, P., Salminen, S., \& Ahokas, J. (2000). Ability of Lactobacillus and Propionibacterium strains to remove aflatoxin $B$, from the chicken duodenum. J Food Prot, 63(4), 549552. doi:10.4315/0362-028x-63.4.549

Firmin, S., Morgavi, D. P., Yiannikouris, A., \& Boudra, H. (2011). Effectiveness of modified yeast cell wall extracts to reduce aflatoxin B1 absorption in dairy ewes. Journal of Dairy Science, 94(11), 5611-5619. doi:https:// doi.org/10.3168/jds.2011-4446

Gallo, A., Minuti, A., Bani, P., Bertuzzi, T., Cappelli, F. P., Doupovec, B., . . . Trevisi, E. (2020). A mycotoxin-deactivating feed additive counteracts the adverse effects of regular levels of Fusarium mycotoxins in dairy cows. Journal of Dairy Science, 103(12), 1131411331. doi:https://doi.org/10.3168/ jds.2020-18197

Goering, H.K. and Van Soest, P. J. (1970). Forage Fiber Analysis (Apparatus Reagents, Procedures and Some Applications). Agriculture Handbook. Washington DC: United States Department of Agriculture. 
Diambil dari https://books.google. co.id/s? id =yn 8wAAAAYAAJ\&printse $c=$ frontcover \&hl=id\&source $=$ gbs_ge ummary_r\&cad $=0 \# \mathrm{v}=$ onepage $\& \mathrm{q} \& \mathrm{f}=$ false

Gonçalves, B. L., Muaz, K., Coppa, C. F. S. C., Rosim, R. E., Kamimura, E. S., Oliveira, C. A. F., \& Corassin, C. H. (2020). Aflatoxin M1 absorption by non-viable cells of lactic acid bacteria and Saccharomyces cerevisiae strains in Frescal cheese. Food Research International, 136, 109604. doi:https://doi. org/10.1016/j.foodres.2020.109604

Haskard, C. A., El-Nezami, H. S., Kankaanpää, P. E., Salminen, S., \& Ahokas, J. T. (2001). Surface binding of aflatoxin B(1) by lactic acid bacteria. Appl Environ Microbiol, 67(7), 3086-3091. doi:10.1128/AEM.67.7.30863091.2001

Jiang, Y., Ogunade, I. M., Pech-Cervantes, A. A., Fan, P. X., Li, X., Kim, D. H., . . Adesogan, A. T. (2020). Effect of sequestering agents based on a Saccharomyces cerevisiae fermentation product and clay on the ruminal bacterial community of lactating dairy cows challenged with dietary aflatoxin B1. Journal of Dairy Science, 103(2), 1431-1447. doi:https://doi.org/10.3168/jds.201916851

Kankaanpää, P., Tuomola, E., El-Nezami, H., Ahokas, J., \& Salminen, S. J. (2000). Binding of aflatoxin B1 alters the adhesion properties of Lactobacillus rhamnosus strain GG in a Caco-2 model. Journal of Food Protection, 63(3), 412-414. https://doi. org/10.4315/0362-028X-63.3.412

Kiessling, K. H., Pettersson, H., Sandholm, K., \& Olsen, M. (1984). Metabolism of aflatoxin, ochratoxin, zearalenone, and three trichothecenes by intact rumen fluid, rumen protozoa, and rumen bacteria. Appl Environ Microbiol, 47(5), 1070-1073. doi:10.1128/ aem.47.5.1070-1073.1984

Lay, B. W. (1994). Analisis Mikrobiologi di Laboratorium. Jakarta: Raja Graffindo Persada.

Lee, Y. K., El-Nezami, H., Haskard, C. A., Gratz, S., Puong, K. Y., Salminen, S., \& Mykkänen, H. (2003). Kinetics of adsorption and desorption of aflatoxin B1 by viable and nonviable bacteria. Journal of Food Protection, 66(3), 426-430. https://doi. org/10.4315/0362-028X-66.3.426.

Lettat, A., Nozière, P., Silberberg, M., Morgavi, D. P., Berger, C., \& Martin, C. (2010). Experimental feed induction of ruminal lactic, propionic, or butyric acidosis in sheep. J Anim Sci, 88(9), 3041-3046. doi:10.2527/jas.20102926

Liu, N., Wang, J., Deng, Q., Gu, K., \& Wang, J. (2018).
Detoxification of aflatoxin B1 by lactic acid bacteria and hydrated sodium calcium aluminosilicate in broiler chickens. Livestock Science, 208, 28-32. doi:https://doi. org/10.1016/j.livsci.2017.12.005

Mansfield, H. R., Endres, M. I., \& Stern, M. D. (1995). Comparison of microbial fermentation in the rumen of dairy cows and dual flow continuous culture. Animal Feed Science and Technology, 55(1), 47-66. doi:https://doi. org/10.1016/0377-8401(95)98202-8

Mc Donald, P., A., E., JFD., G., \& CA., M. (2002). Animal Nutrition, 7th Ed. Edition. Longman Scientific and Technical Co. Published in The United States with John Willey and Sons Inc. New York.United States with John Willey and Sons Inc. New York.

Ogimoto, K. a. S. I. (1981). Atlas of Rumen Microbiology. Japan: Japan Scientific Societies Press, Tokyo

Pantaya, D., Morgavi, D. P., Silberberg, M., Martin, C., Suryahadi, Wiryawan, K. G., \& Boudra, H. (2016). Bioavailability of aflatoxin B 1 and ochratoxin A, but not fumonisin B 1 or deoxynivalenol, is increased in starchinduced low ruminal $\mathrm{pH}$ in nonlactating dairy cows. Journal of Dairy Science, 99(12), 9759-9767. https://doi.org/10.3168/ jds.2016-11421.

Park, W., Park, M. Y., Song, G., \& Lim, W. (2019). Exposure to aflatoxin B1 attenuates cell viability and induces endoplasmic reticulum-mediated cell death in a bovine mammary epithelial cell line (MAC-T). Toxicology in Vitro, 61, 104591. doi:https:// doi.org/10.1016/j.tiv.2019.104591.

Rahayu, R. I., Subrata, A., \& Achmadi, J. (2018). Fermentabilitas Ruminal In Vitro pada Pakan Berbasis Jerami Padi Amoniasi dengan Suplementasi Tepung Bonggol Pisang dan Molases. 2018, 20(3), 9. doi:10.25077/ jpi.20.3.166-174.2018.

Silva, L. J., Pena, A., Lino, C. M., Fernández, M. F., \& Mañes, J. (2010). Fumonisins determination in urine by LC-MS-MS. Anal Bioanal Chem, 396(2), 809-816. doi:10.1007/ s00216-009-3231-9

Upadhaya, S. D., Park, M. A., \& Ha, J. K. (2010). Mycotoxins and Their Biotransformation in the Rumen: A Review. Asian-Australas J Anim Sci, 23(9), 1250-1260. doi:10.5713/ ajas.2010.r.06

Usman, Y. (2013). Pemberian Pakan Serat Sisa Tanaman Pertanian (Jerami Kacang Tanah, Jerami Jagung, Pucuk Tebu) Terhadap Evolusi pH, N-NH3 dan VFA Di dalam Rumen Sapi. Jurnal Agripet, 13(2), 53-58. https:// doi.org/10.17969/agripet.v13i2.821 
Wulandari, S., Agus, A., Cahyanto, M. N., \& Utomo, R. (2014). Effect of fermented cacao pod supplementation on sheep rumen microbial fermentation. Journal of the Indonesian Tropical Animal Agriculture, 39(3), 167-174. https://doi.org/10.14710/ jitaa.39.3.167-174.
Yao, Y., Gao, S., Ding, X., Zhang, Q., \& Li, P. (2021). Topography effect on Aspergillus flavus occurrence and aflatoxin B1 contamination associated with peanut. Current Research in Microbial Sciences, 100021. doi:https://doi. org/10.1016/j.crmicr.2021.100021 